\title{
東北地方太平洋沖地震津波の遡上による地形変化が 波崎海岸において何故少ないか?
}

\author{
Reason why topography change by tsunami run-up of 2011 \\ Tohoku earthquake is small in Hasaki coast
}

\author{
柳嶋慎 ${ }^{1}$
}

\author{
Shin-ichi YANAGISHIMA
}

\begin{abstract}
Factors of small erosion on the land side above the L.W.L. by the tsunami run-up were examined. About the tsunami run-up frequency, tsunamis that cause the topography change for the beach was four times. About the sediment grain diameter, the beach was covered with the coarse sand. Therefore, the ground-water rising with the infiltrating seawater was small. The berm erosion was not caused. About the subsidence, the subsidence due to the earthquake was $0.12 \mathrm{~m}$ and the dune height was enough. The tsunami run-up did not exceed the dune top.
\end{abstract}

\section{1. はじめに}

2011 年に発生した東北地方太平洋沖地震による津波 は，宮城県，福島県の開放的な海岸において甚大な被害 を与え, 茨城県大洗港および千葉県飯岡漁港周辺で被害 が生じた.

田中ら（2011）は，仙台海岸の現地調査および空中写 真の解析により, 旧川河口位置, 海岸構造物不連続部な どの流れが集中する場所で海岸侵食は増大し, 佐藤ら （2011）は，福島県勿来海岸の現地調查により，津波の 遡上は一様であるが, 遡上した水塊が海に戻る時には, 海岸堤防が倒壊した箇所に集中し, 砂州が侵食されたと 指摘している.

波崎海岸においては，津波の遡上がD.L.+10.10mにも 及んだものの, 地形変化は少なかった（柳嶋ら，2011）.

本研究では, 波崎海洋研究施設周辺において, 津波の 遡上にともなう地形変化が干潮面よりも高い範囲で少な かった要因を, 津波遡上波数, 砂浜の底質粒径, 地盤沈 下に注目し検討を行った.

\section{2. 調查方法}

調査は, 図-1に示す，茨城県神栖市の鹿島灘に面する 波崎海洋研究施設 (以後, HORS と呼ぶ) 周辺海岸で実 施した. HORSでは, 平均汀線付近にある観測栈橋建物 （図-2）の沖側かつ栈橋の銚子側サイドを原点とし, 岸沖 方向を $y$ 軸 (沖方向を + ), 沿岸方向を $x$ 軸（銚子方向 を+）とするHORS 固有の座標系を使用している。また， 高さの基準は，波崎港工事基準面（D.L.0m=T.P.-0.687m） を使用している.
津波遡上波形の測定には, 図-2に示す, HORSの後浜 に設置した地下水位・水温計（ダイバー水位・水温計, 自記式, サンプリング間隔 $=10$ 分）を用い, $y=-65 \mathrm{~m}$ の位 置の観測井戸（写真-1）内で測定した（柳嶋ら2011参 照).

津波遡上時の地下水位と地下水温の変化状況を確認す るために，2012年 2 月 20 日に海水 $40 \ell$ を観測井戸に注水 し, 地下水位・水温を測定した（サンプリング間隔 $=1$ 分).

遡上痕跡は, GPS 測量器を用い, 2011 年 3 月 14 日午前 中に測定した（詳細は，柳嶋ら 2011参照).

底質の柱状試料を，地下水位計が設置された，測線 $x=0 \mathrm{~m}$ の $y=-60 \mathrm{~m}, y=-40 \mathrm{~m}$ の 2 地点で，2010年 9 月 30 日に, $y=-70 \mathrm{~m}, y=-50 \mathrm{~m}$ の 2 地点で, 2011年3月 15 日に採取した. 試料の採取は, 各地点とも地表面から $5 \mathrm{~cm}$ 毎に, 約 $1 \mathrm{~m}$ の深さまで行い, 粒度分析は, 試料の水洗い乾燥後, 自 動砂フルイ装置（ロボットシフターRPS-205）によって 行った.

栈橋に沿う断面地形は，2010年9月24，30日，2011年 3 月 11,14 日に岸沖方向間隔 $5 \mathrm{~m}$ で，レベル・スタッフお

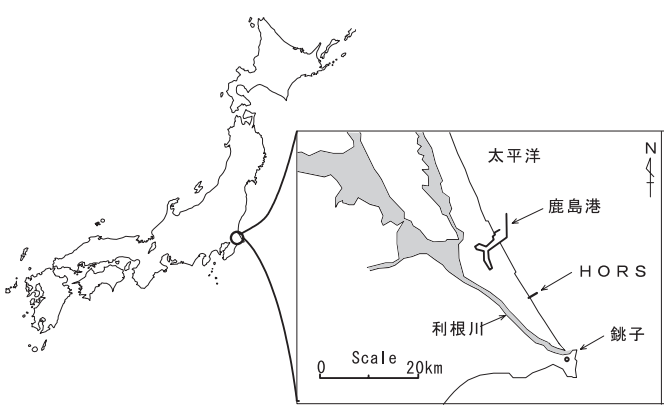

図-1 調査位置図 


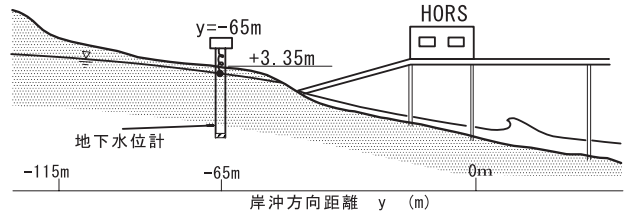

図-2 地下水位計の配置

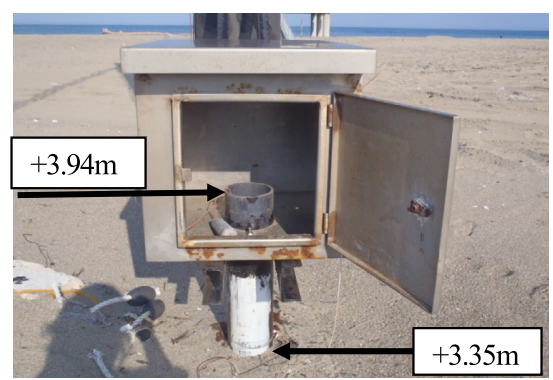

写真-1 観測用井戸

よびレッドにより測定した。地形の平面測量は，3月 14 日にHORSを中心に沿岸方向 $400 \mathrm{~m}$ の範囲を $40 \mathrm{~m}$ 間隔で, 砂丘の付け根から汀線付近までの範囲（約 $120 \mathrm{~m} ）$ を岸沖 方向間隔 $5 \mathrm{~m}$ で，レベル・スタッフにより，測量した. また，3月14日には砂丘付近の詳細な地形を調べるため に，地形測量測線の陸側の範囲（砂丘の陸側〜砂丘頂部 〜砂丘付け根）および沿岸方向 $40 \mathrm{~m}$ の測線の間に，遡上 痕跡の高い測線と低い測線を追加し, GPS 測量器により 測量した.

水面波形は，観測栈橋先端に取り付けた空中発射式超 音波波高計により，風速は，観測栈橋先端のD.L.+10mの 位置に取り付けたコーシンベーン式風向・風速計によ り，大気圧は，観測栈橋上の建物内に設置した気圧計に より測定している，風速は，正時前10分間の平均値を計 算し，水位，大気圧は， 1 時間毎に正時をはさむ 20 分間 のデー夕の平均を求め，有義波高は，同上デー夕から計 算している.

地震による地盤の変動を測定するために，2011年3月 28日に, GPS測量器（Trimble 5800）による精密スタテ イック測量をHORSの基準点1について行った。観測時 間は、2 時間であり，計算の際の比較電子基準点は，茨 城鹿島，銚子，干潟の3地点である.

\section{3. 津波の遡上}

図-3 は，津波遡上波形（青線）と地下水温（赤線）記 録を示している．図中には，井戸上端と地盤高を点線で， 海水温（汀線から $175 \mathrm{~m}$ 海側，D.L.-1mの位置で，サーミ スター式水温計により 1 時間毎に 20 分計測し平均值を計 算）を緑線で示した。なお，11日15時から13日7時まで の間の海水温デー夕は，停電により欠測したので補間し

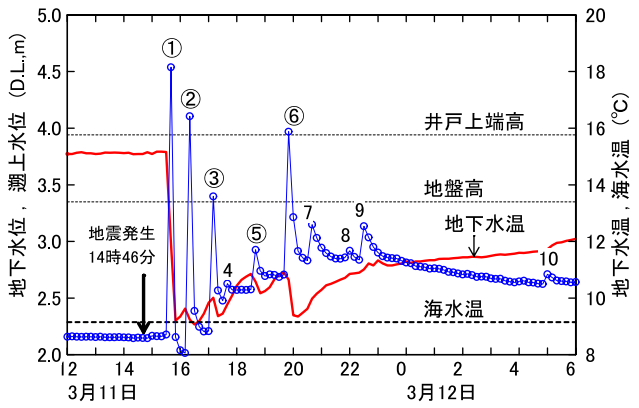

図-3 津波遡上波形と地下水温の変化

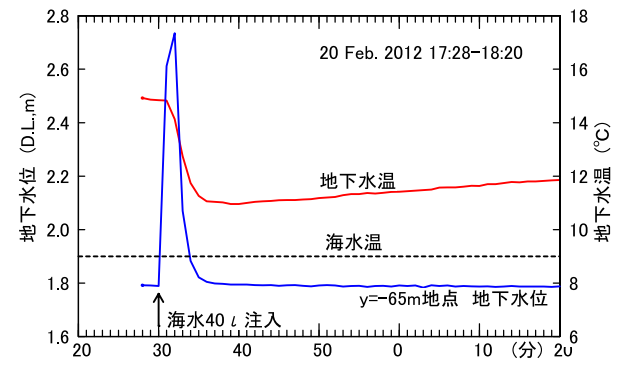

図-4 海水注入による地下水位と地下水温の変化

ている.

津波の第 1 波は，地震発生（3月11日，14時46分） か ら 54 分後の 15 時 40 分に遡上し, 水位は最大 $(+4.54 \mathrm{~m})$ になっている。そして，津波は，3月12日5時までの間 に波崎海岸に合計10波遡上している.

地震発生前の地下水温は, $15^{\circ} \mathrm{C}$ であり, 第(1)波目の津 波の遡上により，遡上水位は急激に上昇するとともに， 地下水温は急激に低下し, 緑線で示す海水温 $\left(9^{\circ} \mathrm{C}\right)$ と 同じになっている．同様に，第(2)，(3)，(5)，6波目の津 波の遡上に伴い地下水温は，低下している。

図-4は，観測井戸内に海水を試験的に注入した際の地 下水位と地下水温の変化を示している. 図中には, 注水 した海水温 $\left(9{ }^{\circ} \mathrm{C}\right)$ を緑線で示してあり, 注水前の地下 水温 $\left(15^{\circ} \mathrm{C}\right)$ とともに，図-3に示した津波遡上時と同じ 条件である。

地下水位は, $20 \ell$ 入りのポリタンク 2 個の海水を井戸 上端から連続注水したことに応答し，約 2 分で $0.95 \mathrm{~m}$ 上 昇し，その 3 分後には，注水前の水位に戻っている.

地下水温は, 海水の注水とともに $11{ }^{\circ} \mathrm{C}$ まで低下し, そ の後は，ゆっくりと上昇して㧍り，図-3に示した津波遡 上時の地下水温の低下，その後の上昇が再現されている.

以上の結果から，第(1)，(2)（3)，(5)，(6)波目の津波の 遡上の際は, 観測井戸上端 $(+3.94 \mathrm{~m})$ から海水が直接井 戸内に入ったため，遡上水位は急激に上昇するとともに， 地下水温は急激に低下したことが分かる。ただし，(5)波 目の津波遡上の際の地下水温は，海水温と同一までは低 
下していないことから，この時の津波高は，井戸上端高 を僅かに越えた程度であったと推察される。

第 $4 ， 7 ， 8 ， 9 ， 10$ 波目の地下水位の上昇量が少ないこ とから, これらの時の津波高は, 地下水位観測地点の地 盤高 $(+3.35 \mathrm{~m})$ より少し高い程度であったと推察される.

従って，波崎海岸に遡上した 10 波の津波の内，後浜を 含め地形変化に大きな影響を及ぼしたのは，第(1), (2), (3)，(6波目の4波のみであったと考えられる.

図-3に示した津波遡上波形に抢いて，第(1)，(2)波目の 津波の遡上の際に，地下水位は全く上昇していない.

台風時の砂浜を観察すると，波の遡上後に砂浜表面の 無数の孔から気泡が出ている現象を確認できる.これは, 砂中の空気が海水の浸透に伴って大気中に排出されるた めである（柳嶋ら，2007）。

写真-2 は, 砂丘近くの高床式建物の 1 階にある倉庫を 示している，この倉庫には，矢印で示す通気口（ $\phi 5 \mathrm{~cm})$ が，地盤から $1.7 \mathrm{~m}$ の位置の海側と陸側の壁にそれぞれ 1 個ずつ設置されている.

この建物の玄関付近に残った津波高痕跡は, D.L.+7.37m（柳嶋ら，2011）であり, 倉庫は, 最大の津 波が遡上した際には, 完全に水没した。 それにもかかわ らず，倉庫内は，写真-3に示すとおり，通気口から海水 が噴射的に入ったのみで，倉庫内の床を濡らすまでには 至らなかった。

倉庫内が浸水しなかったのは，津波が短時間で水位を 増したため, 同一高さに設置された通気口から海水がほ とんど入らず，津波高が通気口よりも高くなると倉庫内 の空気が排出されないため, 海水が倉庫内に入らなかっ たためと考えられる.

砂浜においても, 津波が短時間で遡上痕跡付近まで達 し，台風時に生じたような砂中の空気の排出，海水の浸 透が生じなかったため，第(1)，(2)波目の津波の遡上の際 に，地下水位は上昇しなかったものと考えられる.

第(3)波目以降，地下水位が上昇しているのは，津波高 さが1)，(2)波目より低く，砂中の空気が排出され海水が 浸透したためと考えられる.

\section{4. 底質粒径}

図-3に押いて，第(3)波目の津波の遡上以降，地下水位 （地盤高よりも低い時の水位）は少しずつ上昇している. そして, 津波が引いた後の地下水位の低下スピードは, 一定ではなく, 高さ $+2.8 \mathrm{~m}$ までの水位の低下は速く, そ れょりも低くなると地下水位の低下スピードは, 遲くな っている.

図-5は，観測井戸のある測線 $x=0 \mathrm{~m}$ において，2010年 9 月30日に調査した底質中央粒径の鉛直分布を示している.

図中には，9月24日の断面地形を点線で示してあり,

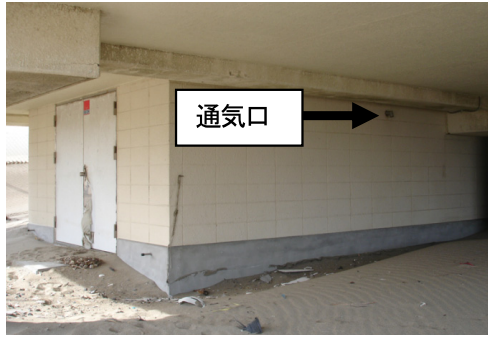

写真-2 倉庫の外観

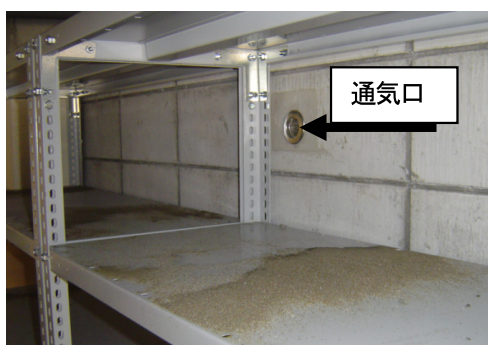

写真-3 倉庫内の浸水状況

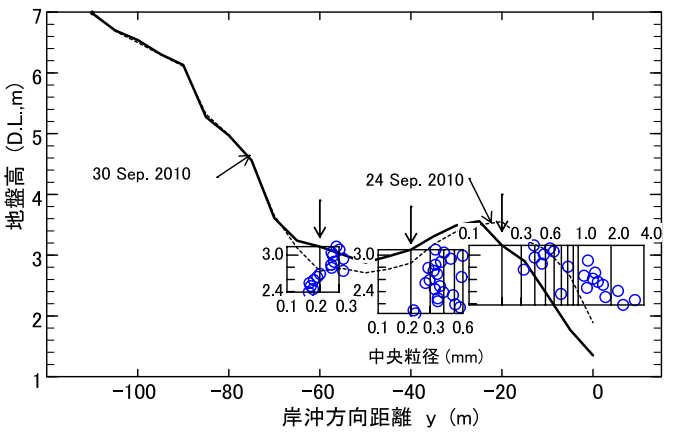

図-5 底質中央粒径の鉛直分布（2010年9月30日採取）

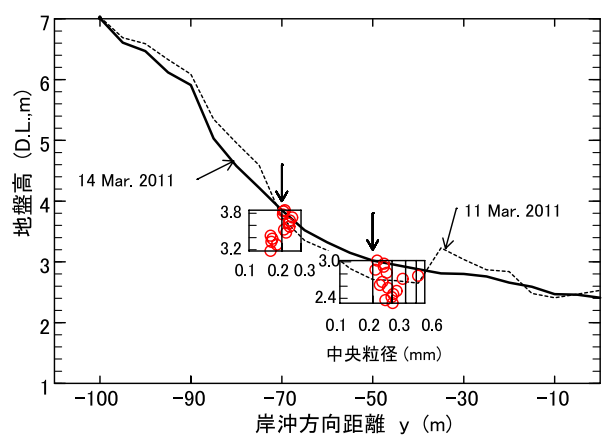

図-6 底質中央粒径の鉛直分布（2011年3月 15 日採取）

24 日から 27 日の間の台風の通過に伴って, 太線で示すよ うに $y=-25 \mathrm{~m} よ り も$ 海側のバームが侵食され，その範囲の 砂が $y=-65 \mathrm{~m} \sim y=-25 \mathrm{~m}$ の間の凹んでいた範囲に運ばれ堆 積した。

海側の $y=-20 \mathrm{~m}$ 地点の底質中央粒径は, 表面が $0.4 \mathrm{~mm}$ で 


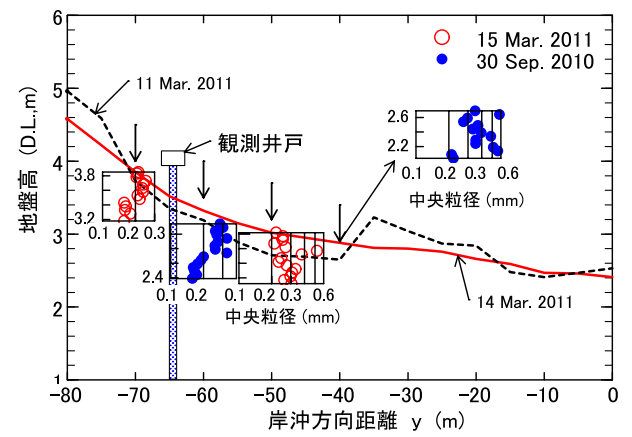

図-7 底質中央粒径の鉛直分布と断面地形

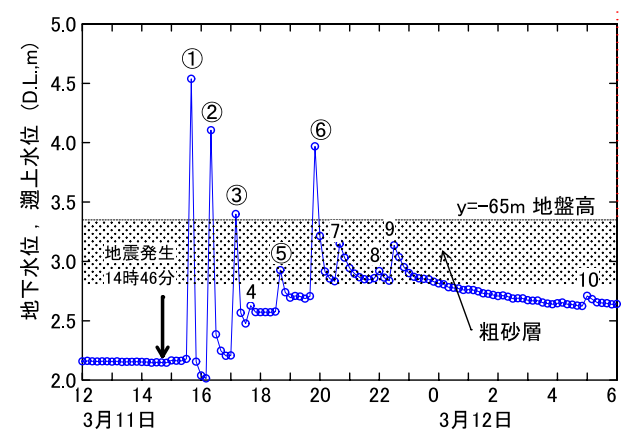

図-8 津波遡上波形と粗砂層

あり，媣くなるほど粒径は粗くなり，深さ $1 \mathrm{~m}$ の地点で は $3 \mathrm{~mm}$ を越えている.

堆積が生じた範囲の底質の中央粒径は, 堆積部分が $0.3 \mathrm{~mm}$ 以上で，これは，海側の粗い砂が運ばれたためと 考えられる. $y=-40 \mathrm{~m}$ 地点の地形変化が生じなかった深さ $0.25 \mathrm{~m}$ から $1 \mathrm{~m}$ の中央粒径は, $0.3 \sim 0.5 \mathrm{~mm}$ であり, $1 \mathrm{~m}$ 以 上媣くなると $0.2 \mathrm{~mm}$ で細かくなっている. $y=-60 \mathrm{~m}$ 地点の 地形変化が生じなかった範囲の中央粒径は， $0.18 \mathrm{~mm}$ 細かい.

このように，バームを構成する部分は全て粗い砂から 成り, 観測井戸のある位置でも, 砂浜表面から深さ $0.4 \mathrm{~m}$ の範囲は, 粗い砂で構成されていることが分かる.

図-6は, 測線 $x=0 \mathrm{~m}$ に打いて, 2011 年 3 月 15 日に調查 した底質中央粒径の鉛直分布と断面地形を示している.

陸側の $y=-70 \mathrm{~m}$ 地点の底質の中央粒径は, 津波によって 堆積した部分で $0.2 \sim 0.25 \mathrm{~mm}$ とやや粗く, それよりも深 くなると $0.18 \mathrm{~mm}$ 以下で細かい. 海側の $y=-50 \mathrm{~m}$ 地点の底 質の中央粒径は, 堆積部分の下層が $0.5 \mathrm{~mm}$ と粗いけれど, それよりも上層, 下層とも $0.2 \sim 0.3 \mathrm{~mm}$ でやや粗くなっ ている.

図-7は，図-5 と図-6に示した中央粒径の鉛直分布を重 ねて示したものである。なお，2010年9月30日のデー夕 の内，2010年9月 30 日から 2011 年3月 11 日までの間に侵 食された部分のデー夕は除外し, 地形が変化していない
部分の底質はそのまま残っていると考え，示してある. 前述のとおり, 観測井戸付近から海側の広範囲に渡っ て, 砂浜表面付近は, 粗い砂で構成されていることが分 かる.

図-8は，津波遡上波形とともに，観測井戸付近の粗砂 層を黒色の網掛けで示したものである.

地下水位低下スピードが速い範囲と粗砂層の範囲は一 致し, 地下水位低下スピードが遅い範囲は, 粗砂層の下 側（細かい砂層）になっている.

津波が繰り返し遡上したにもかかわらず，地下水位が 地表面まで達しなかったのは，砂浜の表面付近に粗砂層 が存在し, 浸透水の浸出が速やかに行われたためと考え られる。

加藤・柳鴆（1992）の研究によって, 底質の中央粒径 が $0.18 \mathrm{~mm}$ の砂浜海岸で荒天時に生じる急激な前浜の侵 食は，（1）長周期波がバームを越えて浜の高い位置まで 遡上し，（2）滞水した海水が浜に浸透して地下水位が上 昇し，（3）さらに海水が前浜から浸出するところが侵食 を受ける，という連鎖が繰り返されて進行することが， 明らかになっている.

従って, 東北地方太平洋沖地震津波の遡上によって, バームが侵食されなかったのは, 砂浜内の地下水位が地 表面まで達しなかったためと考えられる.

\section{5. 地盤沈下}

国土地理院（2011）によれば，東北地方太平洋沖地震 によって地盤沈下が生じ，2011年4月5日から 10 日まで の観測により, 岩手県大船渡市, 宮城県東松島市の電子 基準点は，それぞれ， $0.76 \mathrm{~m} ， 0.47 \mathrm{~m}$ 沈下した。 そこで, HORSに打ける東北地方太平洋沖地震による地盤沈下量 を検討した。

HORSにおいて, 有義波高 $1 \mathrm{~m}$ 以下, 平均風速 $3 \mathrm{~m} / \mathrm{s}$ 以下, 気圧偏差 $5 \mathrm{Hps}$ 以下の条件（選定条件と呼ぶ）の下で, 栈 橋先端の平均水位は天文潮位に一致することが分かって いる（加藤ら 1989）.

図-9は, 地震発生前の 2011年3月9日から 11 日 14 時ま での間で選定条件を満たす栈橋先端平均水位と天文潮位 との関係を示しており，両者は，1対 1 の関係を示す直線 の迴りに分布している.

図-10は，地震後の3月13日から14日までの間で選定 条件を満たす栈橋先端平均水位と天文潮位との関係を示 している. 栈橋平均水位は, 天文潮位よりも平均的に $0.12 \mathrm{~m}$ 高くなっている.この水位の差は, HORSにおけ る地盤沈下量を現しており, 東北地方の地盤沈下量に比 べ小さい.

表-1は, HORSの基準点1の精密スタティック測量結果 （世界測地系）を示している。ここで, 地震前の值は, 
2007年4月に実施したVRSによるGPS 測量の結果である. 基準点 1 の地盤高は，2007年 4 月に比べ $0.077 \mathrm{~m}$ 低下し, 北に $0.046 \mathrm{~m}$ ，東に $0.290 \mathrm{~m}$ 移動したことが分かる.

地盤沈下量は, 図-10に示した地震直後の-0.12mか ら-0.077mに変化したので, $0.04 \mathrm{~m}$ 小さくなっている.

このように，地震によって生じた波崎海岸の地盤沈下 は，時間の経過とともに解消されつつある.

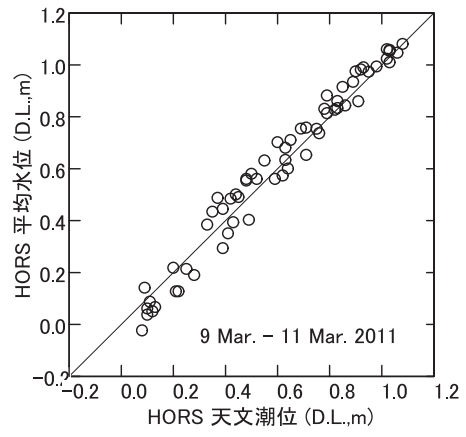

図-9 地震発生直前の平均水位と天文潮位の関係

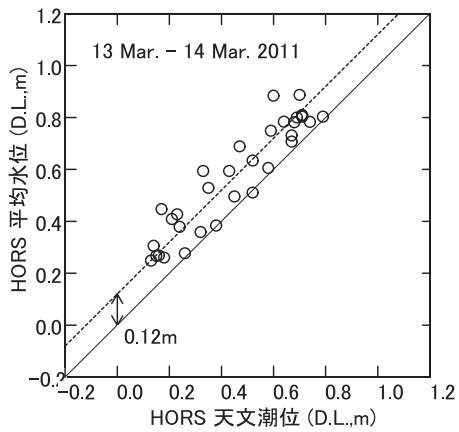

図-10 地震直後の平均水位と天文潮位の関係

表-1 基準点1のスタテイック測量結果

\begin{tabular}{c|r|r|r}
\hline 座 標 & \multicolumn{1}{c|}{ X (南北) } & \multicolumn{1}{c}{$\mathrm{Y}$ (東西) } & \multicolumn{1}{c}{$\mathrm{Z}$} \\
\hline 地震前 $(2007 / 04)$ & -17326.313 & 83796.257 & 10.319 \\
\hline 地震後 $(2011 / 03 / 28)$ & -17326.359 & 83796.547 & 10.242 \\
\hline 変 位 & 0.046 & 0.290 & -0.077 \\
\hline
\end{tabular}

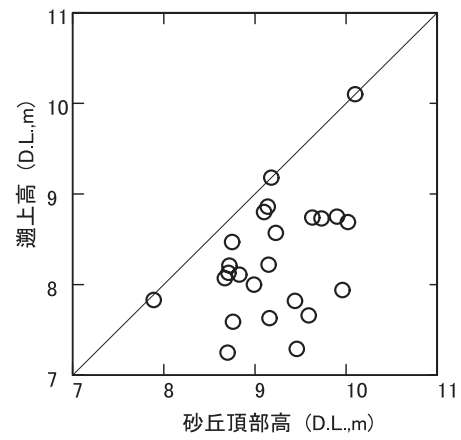

図-11 砂丘頂部高と遡上高の関係
図-11は，代表的な 24 測線の遡上痕跡高（柳嶋ら, 2011）とその測線の砂丘頂部の高さとの関係を示したも のである。

砂丘頂部高と遡上痕跡高がほぼ同一のデータが3測線 あるけれども，ほとんどのデー夕は，砂丘頂部高よりも 遡上痕跡高の方が低くなっている.つまり, 波崎海岸に おいて, 津波は砂丘を越えて陸側に侵入することはなか った。

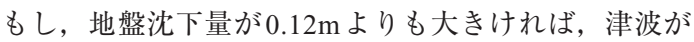
沈下した砂丘頂部を越え, 砂丘の侵食が生じた可能性が 高い.

\section{6. おわりに}

波崎海岸において, 東北地方太平洋沖地震津波遡上に ともなう地形変化が干潮面よりも高い範囲で少なかった 要因を, 津波遡上波数, 底質粒径, 地盤沈下に注目し検 討した。波崎海岸で地形変化が少なかったは, 以下のた めである。

（1）地形変化に影響を及ぼしたと考えられるのは，遡上 した10波の津波のうち，4波である.

（2）砂浜表面の粗砂層により地下水位が地表面まで上昇 しなかったため，バームの侵食は生じなかった。

（3）地震に伴う地盤沈下量は， $0.12 \mathrm{~m}$ と少なく，津波が 砂丘頂部を越えなかったため, 砂丘部の侵食が生じな かった。

謝辞：本論文の作成にあたり，港湾空港技術研究所特別 研究官栗山善昭氏, 上席研究官中村聡志氏から有益な助 言をいただいた。ここに記し，深謝の意を表する.

\section{参 考 文 献}

加藤一正・柳嶋慎一（1992）：長周期波によるバームの侵食, 土木学会論文集, No.452/II-20, pp.41-50.

加藤一正・柳嶋慎一・磯上知良・村上裕幸（1989）：波による 汀線付近の水位上昇量一波崎海洋研究施設における現地 観測 - , 港湾技術研究所報告, 第28巻, 第 1号, pp.3-41. 国土地理（2011）：平成23年（2011）東北地方太平洋沖地震に 伴う地盤沈下調查結果について, http://www.gsi.go.jp/ sokuchikijun/sokuchikijun60008.html（オンライン), 参照 2011-07-07.

佐藤慎司・武若 聡 - 劉 海江 ·信岡尚道 (2011)：2011東北 地方太平洋沖地震津波による福島県勿来海岸における被 害，土木学会論文集B2，Vol.67，No.2，I_1296-I_1300.

田中 仁·真野 明・有働恵子 (2011)：2011東北地方太平洋 沖地震津波による海浜地形変化, 土木学会論文集 B2, Vol.67, No.2, I_571- I_575.

柳嶋慎一 - 加藤一正・長谷川 嚴 - 岩佐直人 (2007) : 透水層埋 設による海浜の安定化, 土木学会論文集 B, Vol.63, No.1, 73-91.

柳嶋慎一 - 中村聡志 - 伴野雅之 - 山田雅仁（2011）：東北地方 太平洋沖地震による波崎海岸における津波の遡上と地形 変化, 土木学会論文集 B2, Vol.67, No.2, I_236- I_240. 